\title{
Incidence of non-hereditary amyloidosis in Poland
}

\author{
Wskaźnik zachorowalności na niedziedziczną amyloidozę w Polsce \\ Władysław Grzeszczak' ${ }^{1}$, Edward Franek ${ }^{2,3}$ (D) ${ }^{\text {Agnieszka Szypowska4 }}{ }^{(\mathbb{D})}$, Winicjusz Filipow ${ }^{5}$ (D), \\ Mariusz Zięba ${ }^{6}$, Paweł Kabicz ${ }^{6}$, Barbara Więckowska ${ }^{6,7}$ \\ 1Department of Internal Medicine, Diabetology and Nephrology, Faculty of Medical Sciences in Zabrze, \\ Medical University of Silesia, Katowice, Poland \\ ${ }^{2}$ Mossakowski Medical Research Centre, Polish Academy of Sciences, Warsaw, Poland \\ ${ }^{3}$ Department of Internal Diseaes, Endocrinology and Nephrology, Central Clinical Hospital MSWiA, Warsaw, Poland \\ ${ }^{4}$ Department of Paediatrics, Medical University of Warsaw, Warsaw, Poland \\ ${ }^{5}$ Department of Research and Development and Innovative Medicine for Metabolic Diseases, Diabetica Clinic, Nysa, Poland \\ ${ }^{6}$ Department of Analysis and Strategies, Ministry of Health, Warsaw, Poland \\ ${ }^{7}$ Department of Social Insurance, Warsaw School of Economics, Warsaw, Poland
}

\section{ABSTRACT}

INTRODUCTION: In the present study we report on the incidence of non-hereditary amyloidosis based on data from public health services in Poland, covering both inpatients and outpatients. Data are given by amyloidosis subtypes between 2013 through 2015.

MATERIAL AND METHODS: Amyloidosis patients were identified from the National Health Fund database. In order to ensure that the reported incidence data included only new patients, persons previously entered in the register with an amyloidosis diagnosis were excluded. Children and adults (males and females) were included in the study. The geographic region of residence was divided into six regions. People with a comparable genome live in all regions of Poland.

RESULTS: In the years 2013 to 2015 a total of 287 patients with amyloidosis were identified, giving an incidence of 2.49 per million person-years. Unspecified amyloidosis was the largest disease category with 169 patients (1.46 per million person-years), and organ-limited amyloidosis - 60 patients ( 0.52 per million person-years $)$ - was the second most frequent. Men had a somewhat higher incidence than women in each of the analysed disorders. There was no statistically significant difference between the recorded incidence in the analysed regions. There are no significant differences between men and women with senile amyloidosis.

CONCLUSIONS: The incidence of amyloidosis in Poland is about 2.49 per million person-years, with a slightly higher risk in men than in women. The patients most often suffered from amyloidosis due to an undetermined cause unrelated to heredity. Organ-limited amyloidosis was second in terms of incidence. There were no statistically significant differences between the registered incidence of amyloidosis in the individual analysed regions of Poland. There were no significant differences between men and women with senile amyloidosis.

\section{KEY WORDS}

non-hereditary amyloidosis, incidence, 2013-2015, Poland

Received: 14.05.2018 Revised: 28.07.2021 Accepted: 25.08.2021 Published online: 27.10 .2021

Adres do korespondencji: prof. dr hab. n. med. Władysław Grzeszczak, Klinika Chorób Wewnętrznych, Diabetologii i Nefrologii, Wydział Nauk Medycznych w Zabrzu, Śląski Uniwersytet Medyczny w Katowicach, ul. 3 Maja 13, 41-800 Zabrze, tel. +48 3237044 88, e-mail: wgrzeszczak@sum.edu.pl

Copyright @ Śląski Uniwersytet Medyczny w Katowicach

www.annales.sum.edu.pl 


\section{ABSTRACT}

WSTĘP: W pracy przedstawiono przypadki niedziedzicznej amyloidozy na podstawie danych z publicznej służby zdrowia w Polsce, obejmujących zarówno pacjentów hospitalizowanych, jak i ambulatoryjnych. Dane przedstawiono według podtypów amyloidozy rozpoznanych w okresie od 2013 r. do 2015 r.

MATERIA I METODY: Pacjenci z amyloidozą zostali wyłonieni z bazy danych Narodowego Funduszu Zdrowia. W celu zapewnienia, że zgłaszane dane dotyczące zachorowalności obejmowały tylko nowych pacjentów, osoby już wcześniej wpisane do rejestru z rozpoznaniem amyloidozy zostały wykluczone. Do badania włączono dzieci i dorosłych obojga płci. Obszar geograficzny (miejsce zamieszkania badanych) podzielono na sześć regionów. We wszystkich regionach Polski mieszkają osoby o porównywalnym genomie.

WYNIKI: W latach 2013-2015 amyloidozę stwierdzono łącznie u 287 pacjentów, z częstością 2,49 na milion osobolat. Najczęstszą z chorób była amyloidoza nieokreślona, cierpiało z jej powodu 169 pacjentów (1,46 na milion osobolat). Druga co do częstości występowania była amyloidoza ograniczona do określonego narządu - 60 pacjentów $(0,52$ na milion osobolat). Biorąc pod uwagę wszystkie analizowane podtypy amyloidozy, mężczyźni chorowali częściej niż kobiety. Nie stwierdzono statystycznie istotnej różnicy między zarejestrowaną zapadalnością w analizowanych regionach. Brak istotnych różnic między mężczyznami i kobietami z amyloidozą starczą.

WNIOSKI: Częstość występowania amyloidozy w Polsce wynosi około 2,49 na milion osobolat, z nieco większym ryzykiem zachorowań u mężczyzn niż u kobiet. Badani chorowali najczęściej na amyloidozę o nieokreślonej przyczynie niezwiązaną z dziedziczeniem. Na drugim miejscu pod względem częstości występowania była amyloidoza ograniczona narządowo. Brak istotnych statystycznie różnic pomiędzy zarejestrowaną zapadalnością na amyloidozę w analizowanych regionach Polski. Nie wykazano istotnych różnic pomiędzy kobietami i mężczyznami chorującymi na amyloidozę starczą.

\section{SŁOWA KLUCZOWE}

amyloidoza niedziedziczna, wskaźnik zachorowalności, 2013-2015, Polska

\section{INTRODUCTION}

The term "amyloidosis" refers to a heterogeneous group of diseases caused by the extracellular deposition of autologous fibrillar proteins, which aggregate into a three-dimensional ß-lamina disposition that attenuates normal organ function. Amyloid is localized in a single organ or systematically in many organs $[1,2,3]$. The term "amyloid" was first used in 1853 by Rudolf Virchow, who observed the close similarity to starch after dyeing these deposits in iodine and sulfuric acid [3].

The disease nomenclature is based on the precursors of the amyloid fibrils for which at least 28 different proteins have been identified $[1,4,5]$. The abbreviations for amyloids are constructed by starting with the character " $A$ " for amyloid and adding a designating precursor protein e.g. AL. AL amyloidosis is the respective disease which is the most common systemic amyloidosis $[2,4,6]$. Other systemic forms include reactive (AA with serum amyloid $\mathrm{A}$ as the precursor) and senile (SSA, transthyretin) amyloidosis [4].

The incidence of amyloidosis is highest among adults aged 60-80 years, whereas prior series show a substantially younger median age at diagnosis of around 45-55 years [7].

There are limited data on the incidence of amyloidosis probably because of the rarity and heterogeneity of the condition.

This work was executed under the project "Map of health needs - database of systemic and implementation analyses" co-funded by the European Union Social Fund from the Operational Program for the development of knowledge education.

In the present study we report on the incidence of non-hereditary amyloidosis based on data from public health services in Poland, covering both inpatients and outpatients. Data are given by subtypes from the National Health Fund between 2013 and 2015.

\section{MATERIAL AND METHODS}

\section{Source of data}

Amyloidosis patients were identified from the National Health Fund (2013-2015). In order to ensure that the reported incidence data included new patients, anyone previously discharged with an amyloidosis diagnosis was excluded.

\section{Outcome variables}

The 10th revision of the International Classification of Diseases (ICD-10) was used to identify all first hospital admissions for the outcome variables of amyloidosis E85: secondary systemic amyloidosis, E85.3; organ-limited amyloidosis, E85.4; other amyloidosis, E85.8; and amyloidosis, unspecified, E85.9. However, as amyloidosis diagnostics is time consuming, the initial discharge may be changed. Therefore, we used the discharge diagnosis of the last hospitalization. Diagnostic details are not included among the discharge data. 


\section{Individual variables}

Children and adults (males and females) were included in the study. The geographic region of residence in 2013-2015 was divided into six regions: Masovian and Silesian regions (the regions with the largest populations - each of them with about 5.0 million habitants), and four other regions (south-east, south-west, north-east and north-west). Comparable inhabitants live in all of these regions.

\section{Statistical analysis}

The results were calculated to provide to information on the incidence of rare metabolic diseases in non-hereditary amyloidosis in Poland according to the region of residence where it occurs, age, sex and subtypes of diagnosis. The person-years were calculated from the start of follow-up on 1 January 2013, until hospitalization for amyloidosis, death or the closing date (31 December 2015). We used RStudio v. 1.0.136 for the statistical analyses. The charts included in the publication were created by using the RStudio data visualization library - ggplot2 version 2.1.0 and Microsoft Excel 2013 (especially for making pie charts).
In part of them, the authors used a logarithmic scale on axes for better presentation of the given phenomenon.

\section{RESULTS}

The case numbers of hospitalized amyloidosis patients are shown in Table I. In the years 2013 to 2015, a total of 287 patients were identified, giving an incidence of 2.49 per million person-years. Unspecified amyloidosis was the largest disease category with 169 patients (incidence 1.46 per million person-years) and organ-limited amyloidosis -60 patients $(0.52$ per million person-years) - was the second most frequent. In Table II, the incidence (incidence per million person-years) divided into men and women is presented. Overall, men had a somewhat higher incidence than women in each of the analysed disorders (1.2-fold for the whole group of non-hereditary amyloidosis). Regardless of sex, the incidence was 2.49 patients per 1 million people.

Figures 1-4 represent the index of the recorded incidence (for 1 million person-years from 2013 to 2015 depending on age and sex). Each graph represents another disease from the analysed group.

Table I. Numbers and incidence of amyloidosis in hospitalized patients, 2013-2015

Tabela I. Zapadalność i liczba chorych hospitalizowanych z powodu amyloidozy w latach 2013-2015

\begin{tabular}{lccccccc}
\hline \multicolumn{1}{c}{ Subtype (ICD-10 code) } & 2013 & $\mathbf{2 0 1 4}$ & $\mathbf{2 0 1 5}$ & Total & $\begin{array}{c}\text { Incidencel } \\
\text { mln child-years }\end{array}$ & $\begin{array}{c}\text { Incidencel } \\
\text { mln adult-years }\end{array}$ & $\begin{array}{c}\text { Incidencel } \\
\text { mln habitant-years }\end{array}$ \\
\hline Secondary systemic amyloidosis (E85.3) & 26 & 24 & 10 & 60 & 0.38 & 0.55 & 0.52 \\
Organ-limited amyloidosis (E85.4) & 6 & 4 & 5 & 15 & 0.00 & 0.16 & 0.13 \\
Other amyloidosis (E85.8) & 20 & 10 & 13 & 43 & 0.14 & 0.42 & 0.37 \\
Amyloidosis, unspecified (E85.9) & 54 & 48 & 67 & 169 & 0.18 & 1.76 & 1.46 \\
\hline All & 106 & 86 & 95 & 287 & 0.67 & 2.89 & 2.49 \\
\hline
\end{tabular}

Table II. Incidence of non-hereditary amyloidosis in men and women Tabela II. Zapadalność na amyloidozę niedziedziczną u mężczyzn i kobiet

\begin{tabular}{|c|c|c|c|c|c|c|c|c|c|}
\hline \multirow{2}{*}{ ICD-10 } & \multicolumn{3}{|c|}{ Men } & \multicolumn{3}{|c|}{ Women } & \multicolumn{3}{|c|}{ All } \\
\hline & $\mathbf{N}$ & IR & $95 \% \mathrm{Cl}$ & $\mathrm{N}$ & IR & $95 \% \mathrm{Cl}$ & $\mathrm{N}$ & IR & $95 \% \mathrm{Cl}$ \\
\hline E85.3 & 31 & 0.56 & 0.360 .75 & 29 & 0.49 & 0.310 .66 & 60 & 0.52 & 0.390 .65 \\
\hline E85.4 & 7 & 0.13 & $0.03 \quad 0.22$ & 8 & 0.13 & $0.04 \quad 0.23$ & 15 & 0.13 & $0.06 \quad 0.20$ \\
\hline E85.8 & 25 & 0.45 & 0.270 .62 & 18 & 0.30 & 0.160 .44 & 43 & 0.37 & $0.26 \quad 0.48$ \\
\hline E85.9 & 86 & 1.54 & $1.21 \quad 1.87$ & 83 & 1.39 & 1.091 .69 & 169 & 1.46 & 1.241 .69 \\
\hline All & 149 & 2.67 & 2.243 .10 & 138 & 2.32 & 1.932 .70 & 287 & 2.49 & $2.20 \quad 2.77$ \\
\hline
\end{tabular}


Age-specific incidence (per million person-years) of patients with $\mathrm{E} 85.3$

2,5

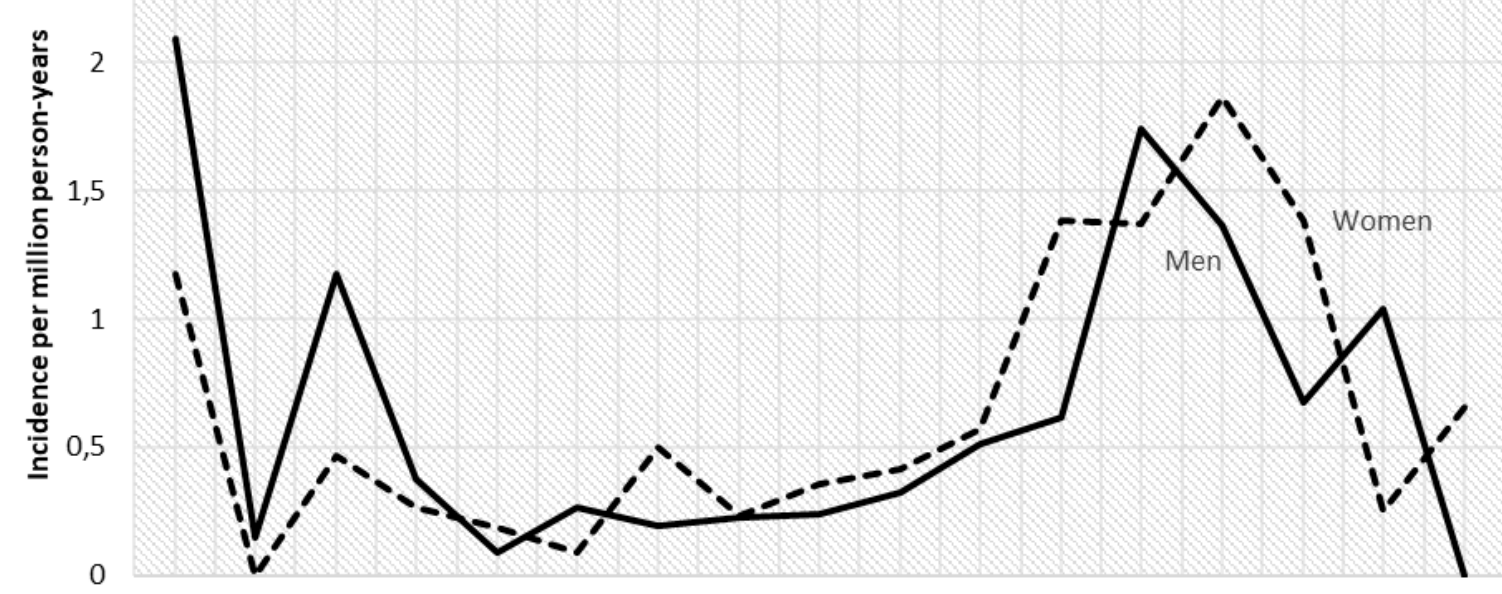

0-4 5-9 10-14 15-19 25-29 30-34 35-39 40-44 45-49 50-54 55-59 60-64 65-69 70-74 75-79 80-84 85+ Age at diagnosis (years)

---Women Men

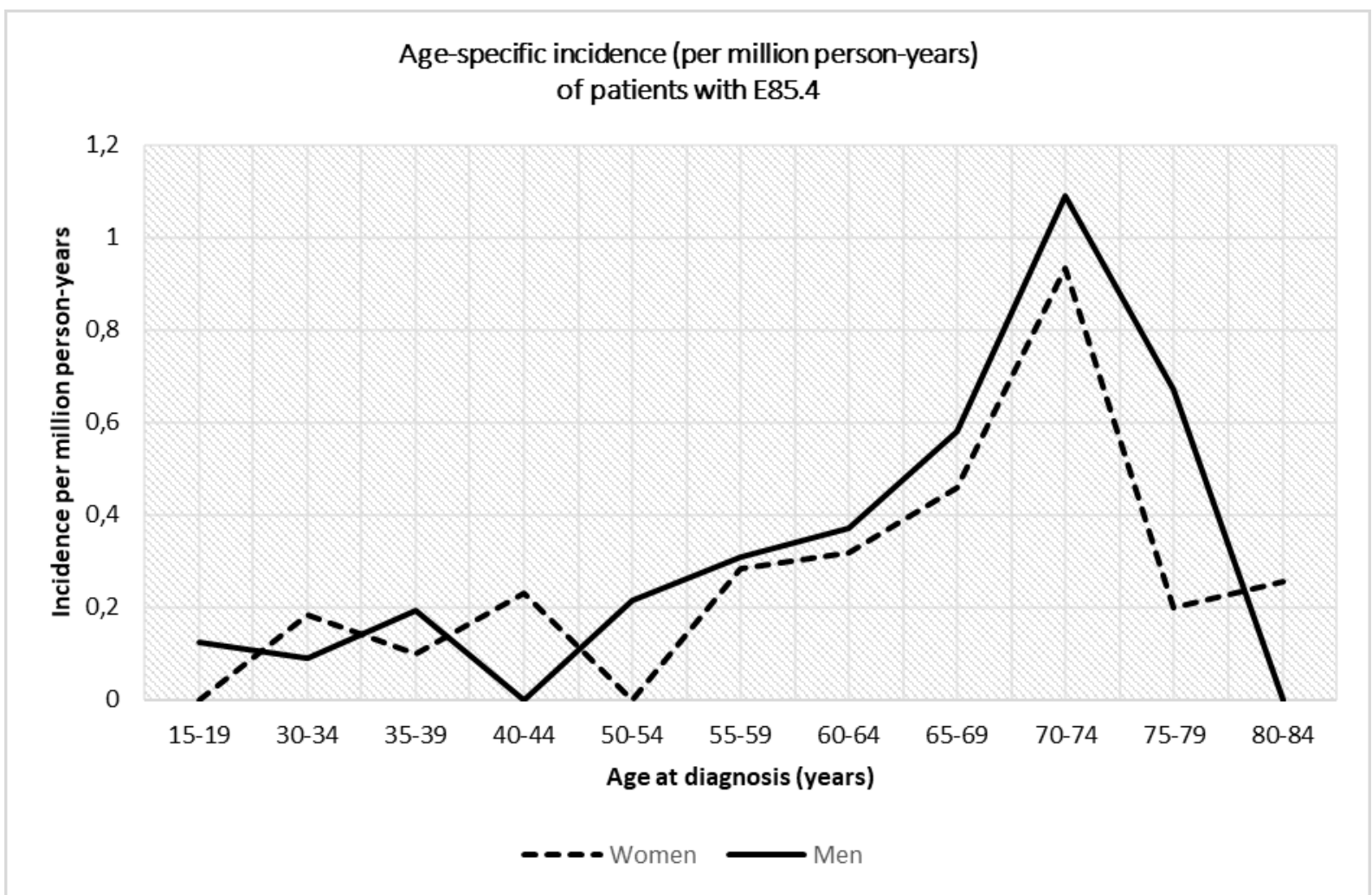

Fig. 2. Organ-limited amyloidosis (E85.4).

Ryc. 2. Amyloidoza ograniczona do określonego narządu (E85.4). 


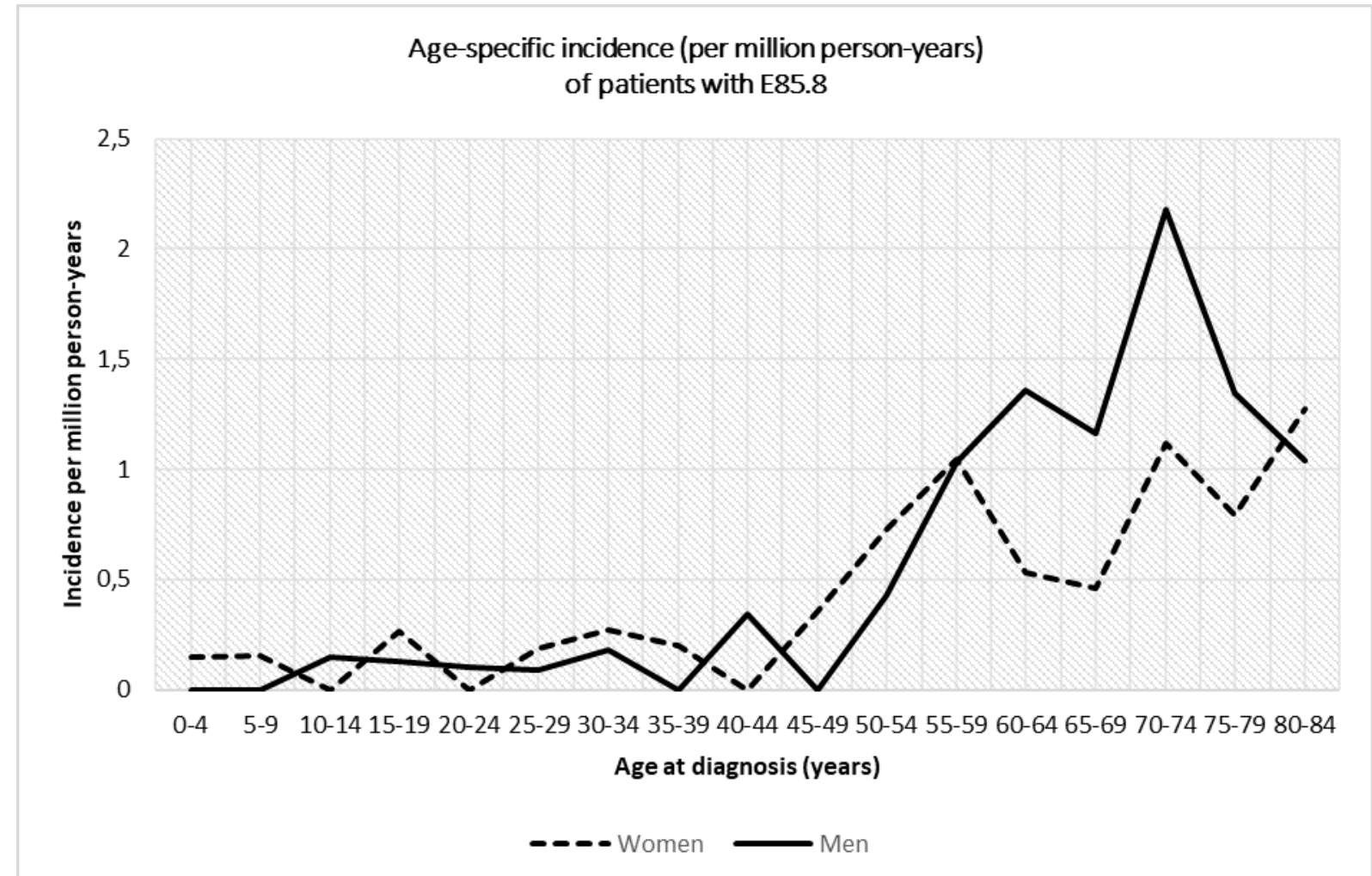

Fig. 3. Other amyloidosis (E85.8).

Ryc. 3. Inne postacie amyloidozy (E85.8).

\section{Age-specific incidence (per million person-years)}

of patients with E85.9

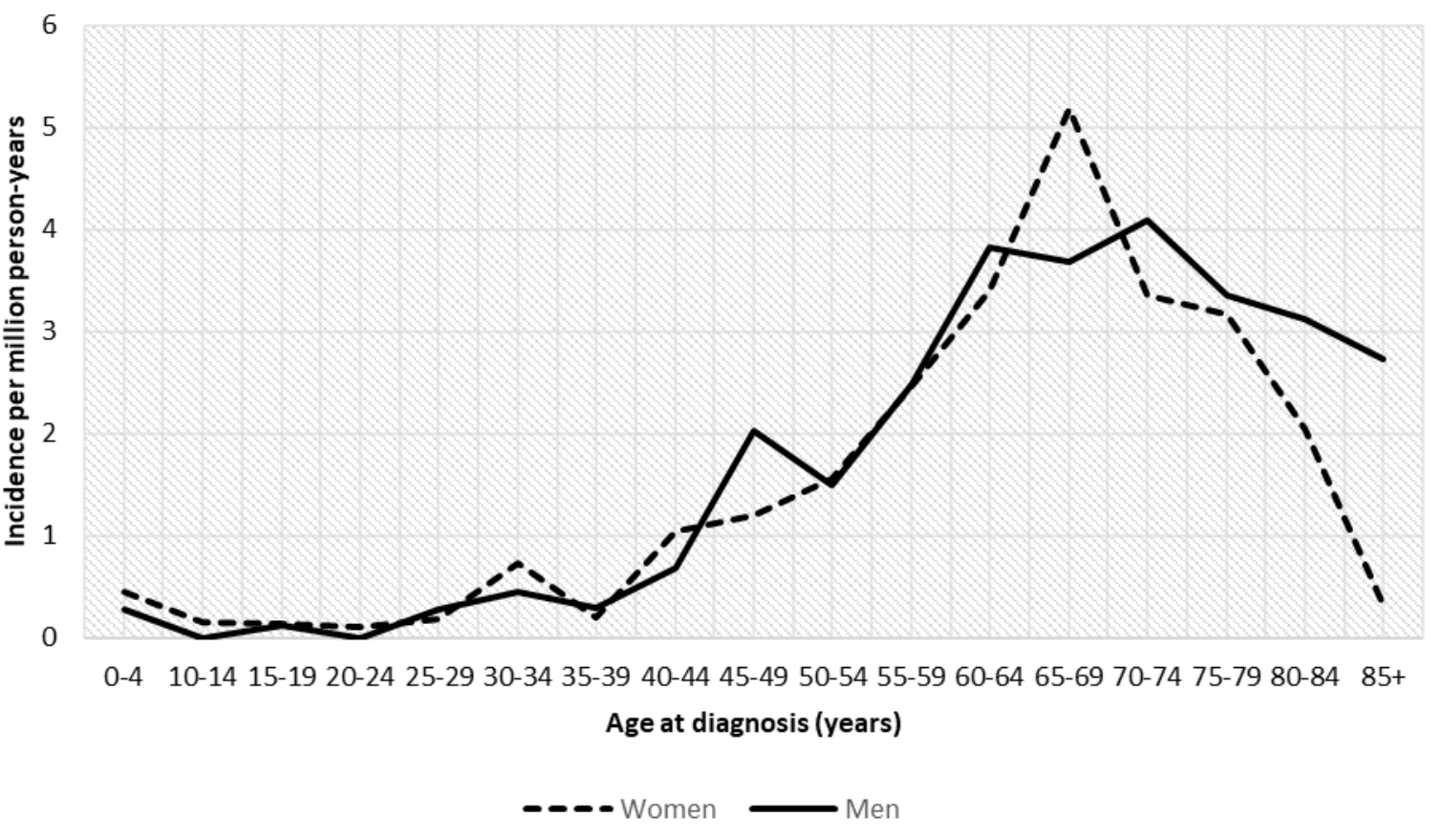

Fig. 4. Amyloidosis, unspecified (E85.9).

Ryc. 4. Amyloidoza nieokreślona (E85.9). 
The highest incidence in secondary systemic amyloidosis is among young people (0-14 years) and among older people (after 64 years). Among young patients, boys are characterized by a greater incidence. The recorded incidence of organ-limited amyloidosis increases with age. The highest values are in the 70-74 age group and are 1.09 for men and 0.93 for women. Men have a greater incidence of localized (organ) deposition of starch masses compared to women.

The recorded incidence for other amyloidosis increases with age. The highest values of this incidence were observed in the age group of 70-74 year-olds. The recorded incidence was 2.17 for men, and was significantly higher than in women -1.16 (the highest incidence for women was in the age group 80-84 and is 1.34). Men have a significantly higher incidence of other amyloidosis after the age of 54 .
The recorded incidence for amyloidosis, unspecified (E85.9) was the highest in the age group 65-69 (5.17 for women and 3.68 for men). The incidence of non-specific amyloidosis is significantly higher than E85.3-E85.8. This seems to be due to the difficulty of identifying the correct disease and coding it as an undetermined form.

The regional differences in the incidence of non-hereditary amyloidosis were also analysed by residence 2013-2015. Detailed data is shown in Table III.

The differences between the individual regions of Poland were analysed, taking into account the place of residence of patients in different regions of the country with non-hereditary amyloidosis in 2013-2015. There was no statistically significant difference between the recorded incidence in the analysed regions.

There are no significant differences between men and women with senile amyloidosis (Table IV).

Table III. Regional differences in incidence of non-hereditary amyloidosis, 2013-2015 Tabela III. Regionalne różnice w zapadalności na amyloidozę niedziedziczną w latach 2013-2015

\begin{tabular}{|c|c|c|c|c|c|c|c|c|c|c|}
\hline \multirow{2}{*}{ ICD-10 } & \multirow{2}{*}{$\begin{array}{c}\text { Region } \\
\text { of residence }\end{array}$} & \multicolumn{3}{|c|}{ Men } & \multicolumn{3}{|c|}{ Women } & \multicolumn{3}{|c|}{ All } \\
\hline & & $N$ & IR & $95 \% \mathrm{Cl}$ & $N$ & IR & $95 \% \mathrm{Cl}$ & $\mathrm{N}$ & IR & $95 \% \mathrm{Cl}$ \\
\hline \multirow{6}{*}{ E85.3 } & Masovian & 8 & 1.05 & 0.321 .77 & 5 & 0.60 & $0.07 \quad 1.12$ & 13 & 0.81 & $0.37 \quad 1.25$ \\
\hline & S-E & 6 & 0.45 & $0.09 \quad 0.80$ & 6 & 0.42 & $0.08 \quad 0.75$ & 12 & 0.43 & 0.190 .68 \\
\hline & S-W & 1 & 0.14 & $-0.13 \quad 0.41$ & 4 & 0.52 & 0.011 .04 & 5 & 0.34 & $0.04 \quad 0.63$ \\
\hline & $N-E$ & 3 & 0.43 & $-0.06 \quad 0.92$ & 6 & 0.81 & $0.16 \quad 1.47$ & 9 & 0.63 & 0.221 .04 \\
\hline & $\mathrm{N}-\mathrm{W}$ & 9 & 0.64 & $0.22 \quad 1.06$ & 8 & 0.54 & $0.17 \quad 0.92$ & 17 & 0.59 & $\begin{array}{lll}0.31 & 0.87\end{array}$ \\
\hline & Silesian & 1 & 0.15 & $-0.14 \quad 0.45$ & - & - & - & 1 & 0.07 & $\begin{array}{lll}-0.07 & 0.22\end{array}$ \\
\hline \multirow{6}{*}{ E85.4 } & Masovian & - & - & - & - & - & - & - & - & - \\
\hline & S-E & 1 & 0.07 & $\begin{array}{lll}-0.07 & 0.22\end{array}$ & 2 & 0.14 & $-0.05 \quad 0.33$ & 3 & 0.11 & $-0.01 \quad 0.23$ \\
\hline & S-W & 1 & 0.14 & $-0.13 \quad 0.41$ & - & - & - & 1 & 0.07 & $\begin{array}{ll}-0.06 & 0.20\end{array}$ \\
\hline & $N-E$ & - & - & - & 6 & 0.81 & $0.16 \quad 1.47$ & 6 & 0.42 & $0.08 \quad 0.75$ \\
\hline & $\mathrm{N}-\mathrm{W}$ & 4 & 0.29 & $0.01 \quad 0.57$ & - & - & - & 4 & 0.14 & $0.00 \quad 0.28$ \\
\hline & Silesian & 1 & 0.15 & $-0.14 \quad 0.45$ & - & - & - & 1 & 0.07 & $\begin{array}{lll}-0.07 & 0.22\end{array}$ \\
\hline \multirow{6}{*}{ E85.8 } & Masovian & 7 & 0.91 & $0.24 \quad 1.59$ & 4 & 0.48 & $0.01 \quad 0.95$ & 11 & 0.69 & 0.281 .09 \\
\hline & S-E & 4 & 0.30 & $0.01 \quad 0.59$ & 6 & 0.42 & $0.08 \quad 0.75$ & 10 & 0.36 & $0.14 \quad 0.58$ \\
\hline & S-W & 4 & 0.56 & $0.01 \quad 1.11$ & 1 & 0.13 & $\begin{array}{ll}-0.13 & 0.39\end{array}$ & 5 & 0.34 & $0.04 \quad 0.63$ \\
\hline & $N-E$ & 5 & 0.72 & $0.09 \quad 1.34$ & 2 & 0.27 & $-0.10 \quad 0.65$ & 7 & 0.49 & $0.13 \quad 0.85$ \\
\hline & $\mathrm{N}-\mathrm{W}$ & 4 & 0.29 & $0.01 \quad 0.57$ & 3 & 0.20 & $-0.03 \quad 0.43$ & 7 & 0.24 & $0.06 \quad 0.42$ \\
\hline & Silesian & 1 & 0.15 & $-0.14 \quad 0.45$ & 1 & 0.14 & $-0.13 \quad 0.42$ & 2 & 0.15 & $\begin{array}{lll}-0.06 & 0.35\end{array}$ \\
\hline \multirow{6}{*}{ E85.9 } & Masovian & 13 & 1.70 & $0.78 \quad 2.62$ & 18 & 2.16 & $1.16 \quad 3.15$ & 31 & 1.94 & 1.262 .62 \\
\hline & S-E & 18 & 1.34 & 0.721 .96 & 12 & 0.84 & $0.36 \quad 1.31$ & 30 & 1.08 & $0.69 \quad 1.47$ \\
\hline & S-W & 9 & 1.26 & $0.44 \quad 2.09$ & 4 & 0.52 & $0.01 \quad 1.04$ & 13 & 0.88 & $0.40 \quad 1.36$ \\
\hline & $N-E$ & 10 & 1.43 & $0.54 \quad 2.32$ & 14 & 1.90 & $0.91 \quad 2.90$ & 24 & 1.67 & $1.00 \quad 2.34$ \\
\hline & $\mathrm{N}-\mathrm{W}$ & 27 & 1.93 & 1.202 .66 & 23 & 1.56 & $0.92 \quad 2.20$ & 50 & 1.74 & $1.26 \quad 2.22$ \\
\hline & Silesian & 7 & 1.05 & $0.27 \quad 1.84$ & 11 & 1.55 & $0.63 \quad 2.46$ & 18 & 1.31 & 0.701 .91 \\
\hline
\end{tabular}


Table IV. Recorded incidence of senile amyloidosis in men and women Tabela IV. Zarejestrowany współczynnik zachorowalności na amyloidazę starczą u mężczyzn i kobiet

\begin{tabular}{|c|c|c|c|c|c|c|c|c|c|c|}
\hline \multirow{2}{*}{ ICD-10 } & \multicolumn{4}{|c|}{ Men } & \multicolumn{3}{|c|}{ Women } & \multicolumn{3}{|c|}{ All } \\
\hline & $\mathbf{N}$ & IR & $95^{\circ}$ & $\% \mathrm{Cl}$ & $\mathbf{N}$ & IR & $95 \% \mathrm{Cl}$ & $\mathbf{N}$ & IR & $95 \% \mathrm{Cl}$ \\
\hline E85.3 & 10 & 1.47 & 0.56 & 2.37 & 11 & 1.02 & $0.42 \quad 1.62$ & 21 & 1.19 & $0.68 \quad 1.70$ \\
\hline E85.4 & 2 & 0.29 & 0.11 & 0.70 & 4 & 0.37 & $0.01 \quad 0.73$ & 6 & 0.34 & $0.07 \quad 0.61$ \\
\hline E85.8 & 11 & 1.61 & 0.66 & 2.57 & 6 & 0.56 & 0.111 .00 & 17 & 0.96 & $0.51 \quad 1.42$ \\
\hline E85.9 & 30 & 4.40 & 2.82 & 5.97 & 31 & 2.87 & $1.86 \quad 3.88$ & 61 & 3.46 & $2.59 \quad 4.33$ \\
\hline All & 53 & 7.77 & 5.68 & 9.86 & 52 & 4.81 & $3.51 \quad 6.12$ & 105 & 5.96 & 4.827 .10 \\
\hline
\end{tabular}

\section{DISCUSSION}

The current study enriches our knowledge with information on amyloidosis in a large Polish population. About 38 million people live in Poland and therefore the data on amyloidosis are very close to true. In our research we have shown that in the years 2013 to 2015, a total of 287 patients were identified, giving an incidence of 2.49 per million person-years.

In order to obtain reliable data in this regard, we have analysed the material of all patients who used the public healthcare system in Poland from 2013 to 2015 using the National Health Fund data. Information on almost everyone of Polish nationality hospitalized in Poland goes to the National Health Fund database. The National Health Fund is the payer of the treatment of all subjects.

Not a great deal of epidemiological data has been published previously for amyloidosis. Until our study, amyloidosis had only been reported through retrospective case series [8]. Kyle et al. [9], having analysed only 21 subjects, reported an incidence of AL amyloidosis in nine cases per million person-years (95\% confidence interval; 5.1-12.8 cases per million person-years). Nonetheless, they analysed a small number of subjects. Recently, similar studies have been carried out in two European regions, the first was in the UK. Pinney et al. [7] estimated a total incidence of amyloidosis in England of five cases per million person-years. Among these cases three cases per million person-years were the AL type, and one case, the AA type. Using similar methods, Hemminki et al. [10] calculated an incidence of 8.29 patients per million person-years in Sweden. In the present paper (based on the study of the whole population of a very large country) the incidence was 2.49 per million person-years. The incidence was therefore about three times lower than in the Swedish population. However, we would like to add here that the Polish population is several times (nearly four times) more than the Swedish population on the one hand, and on the other hand the Polish population is more genetically mixed than the Swedish population. We believe that this could have an indirect effect on the obtained results. Nevertheless, it should not be ruled out that in some of the sufferers incorrect diagnoses were made. In conclusion, it should be emphasized that the incidence is within the limits set out above.

The incidence in the Swedish population [10] was little higher in men than in women (8.59 vs 7.98). Unspecified amyloidosis was the largest disease category, follow by secondary systemic amyloidosis. In the Polish study group a slightly higher incidence of non-hereditary amyloidosis in men (2.75) than in women (2.32) was revealed. This difference, however, was statistically insignificant. No statistically significant differences between the studied men and women in any of the analysed amyloidosis subtypes (Table II) were found. No significant difference in the incidence for men and women in all the types of amyloidosis (E85.3, E85.4, E85.8 and E85.9) was discovered.

In the paper presented by Merlini et al. [4], senile amyloidosis is characterized by a dominance of male incidence (age of onset higher than 64 years); practically all the subtypes in the present study were characterized by a high age male incidence peak and it is not possible to assign any incidence estimate to senile amyloidosis. Organ-limited amyloidosis may be caused by many types of amyloid deposits and it could not be assigned to a specific amyloidosis subtype [11]. The six year median survival for this group is commensurate with limited disease severity. In the Polish population no statistical differences between men and women were revealed (Table IV).

\section{Study limitations}

In analysing the provided data, we believe that errors may have occurred in our analysis.

Firstly, we have doubts that all the cases of amyloidosis included in the "amyloidosis unspecified - E85.9" group belonged to this group of patients. Perhaps a larger number of them through more precise diagnosis analysis would be qualified to another group.

Secondly, similar considerations apply to the group of "other amyloidosis - E85.8".

Thirdly, we believe that some cases of secondary amyloidosis in patients suffering from this condition, especially in small urban centres or in rural 
centres, were not properly diagnosed. Perhaps this is why we found a significantly lower incidence of secondary amyloidosis in the general Polish population compared to the population of, e.g. Sweden.

Nonetheless, in the current work, we present for the first time, fully reliable data on the incidence due to secondary amyloidosis in Poland. To date, not a great deal of data has been published on this topic. For this reason, we believe that it would be extremely beneficial if these data were published. Perhaps they will help to better understand this issue, to improve the diagnosis of this condition, and consequently, to develop more targeted treatment.

\section{REFERENCES}

1. Sipe J.D., Benson M.D., Buxbaum J.N., Ikeda S., Merlini G., Saraiva M.J., Westermark P. Amyloid fibril protein nomenclature: 2010 recommendation from the nomenclature committee of the International Society of Amyloidosis. Amyloid 2010; 17(3-4): 101-104, doi: 10.3109/13506129.2010.526812.

2. Gertz M.A. Immunoglobin light chain amyloidosis: 2011 update on diagnosis, risk-stratification, and management. Am. J. Hematol. 2011: 86(2): 181-186, doi: 10.1002/ajh.21934.

3. Pettersson T., Konttinen Y.T. Amyloidosis-recent developments. Semin Arthritis Rheum. 2010; 39(5): 356-368, doi: 10.1016/j.semarthrit.2008.09.001 4. Merlini G., Seldin D.C., Gertz M.A. Amyloidosis: pathogenesis and new therapeutic options. J. Clin. Oncol. 2011: 29(14): 1924-1933, doi: 10.1200/JCO.2010.32.2271.

5. Bellotti V., Nuvolone M., Giorgetti S., Obici L., Palladini G., Russo P. et al. The workings of the amyloid diseases. Ann. Med. 2007; 39(3): 200-207, doi: 10.1080/07853890701206887.

6. Lachmann H.J., Hawkins PN. Systemic amyloidosis. Curr. Opin. Pharmacol. 2006; 6(2): 214-220, doi: 10.1016/j.coph.2005.10.005.

\section{CONCLUSIONS}

The incidence of non-inherited amyloidosis in Poland is about 2.49 per million person-years, with a slightly higher risk in men than in women.

The patients most often suffered from amyloidosis due to a undetermined cause unrelated to heredity. Organ-limited amyloidosis was second in terms of incidence. There were no statistically significant differences between the recorded incidence of amyloidosis in the individual analysed regions of Poland.

There were no significant differences between men and women with senile amyloidosis.
7. Pinney J.H., Smith C.J., Taube J.B., Lachmann H.J., Venner C.P., Gibbs S.D. Systemic amyloidosis in England: an epidemiological study. Br. J. Haematol. 2013; 161(4): 525-532, doi: 10.1111/bjh.12286.

8. Simms R.W., Prout M.N., Cohen A.S. The epidemiology of AL and AA amyloidosis. Baillieres Clin Rheumatol 1994; 8(3): 627-634, doi: 10.1016/s0950-3579(05)80119-0.

9. Kyle R.A., Linos A., Beard C.M., Linke R.P., Gertz M.A., O'Fallon W.M., Kurland L.T. Incidence and natural history of primary systemic amyloidosis in Olmsted County, Minnesota, 1950 through 1989. Blood 1992; 79(7): 1817-1822

10. Hemminki K, Li X, Försti A Sundquist J, Sundquist K. Incidence and survival in non-hereditary amyloidosis in Sweden. BMC Public Health 2012; 12: 974, doi: 10.1186/1471-2458-12-974.

11. Westermark P., Benson M.D., Buxbaum J.N., Cohen A.S., Frangione B. Ikeda S. et al. A primer of amyloid nomenclature. Amyloid 2007; 14(4): 179-183 , doi: $10.1080 / 13506120701460923$. 